International Journal of Human and Health Sciences Vol. 05 No. 02 April'21

Letter to the Editor

Community use of masks as a preventive measure for Covid-19 in Kabale district of Uganda Mustafa Ssakal, Charles Lwanga ${ }^{2}$, Tunc Eren ${ }^{3}$, Orhan Alimoglu ${ }^{3,4}$

\begin{abstract}
$\underline{\text { Abstract }}$
Coronavirus disease 2019 (Covid-19) caused a global pandemic and by June $1^{\text {st }}, 2020$, the global numbers of Covid-19 cases reached six million with more than 370,000 deaths. Community-wide mask wearing may contribute to the control of Covid-19 by reducing the amount of emission of infected saliva and respiratory droplets from persons with subclinical or mild Covid-19. However, use of masks in public and in health care facilities has been controversial as different organizations and agencies established different guidelines. In Uganda, not any reports on mask utilization practices have been published yet. Therefore, this report aims at documenting mask use practices, as observed in our interactions with non-Covid-19 patients and their relatives at Kabale regional referral hospital as well as Kabale town residents. It was observed that many non-Covid-19 patients and the relatives of hospitalized patients only wear their masks on reaching the hospital premises while community members of Kabale town wear their masks only in the presence of security agencies and individuals in the public only wear masks in places where they would be refused from services without masks. Wearing of masks in public places and health care facilities together with other preventive measures including hand hygiene, social distancing and wearing of full personal protective equipment for health care providers working on Covid-19 patients are key measures in preventing the spread of infection. There is an increased need for intensified community educational activities on public awareness of the importance of appropriate use of masks.

Keywords: COVID-19; pandemics; prevention and control.
\end{abstract}

International Journal of Human and Health Sciences Vol. 05 No. 02 April'21 Page : 267-270 DOI: http://dx.doi.org/10.31344/ijhhs.v5i2.274

\section{Community use of masks as a preventive measure for Covid-19 in Kabale district of Uganda}

In December 2019, a novel coronavirus (SARSCoV-2) emerged in Wuhan, China, sparking an epidemic of acute respiratory syndrome termed as coronavirus disease 2019 (Covid-19) in humans. ${ }^{1}$ It was closely associated to bat borne SARS related coronaviruses and was the second pandemic to be recorded in the $21^{\text {st }}$ century following the influenza A H1N1 pandemic of 2009. . $^{2,3}$ In a period of three months, the virus spread to more than 118,000 individuals and caused 4,291 deaths in
114 countries, hence was declared to be a global pandemic. $^{4}$

By June $1^{\text {st }}, 2020$, the global numbers of Covid-19 cases reached six million with more than 370,000 deaths while Uganda reported 417 cases. ${ }^{5,6}$ The pandemic led to the implementation of proactive infection control measures in hospital settings to prevent rapid spread of the virus. ${ }^{7}$ In addition, public health interventions including border control, quarantine and testing of all incoming travelers or returnees, wearing of face masks, frequent hand hygiene, and social distancing measures were taken by different countries to

1. Intern Doctor, Habib Medical School, Islamic University in Uganda (HMS- IUIU), Kabale Regional Referral Hospital, Southwestern Uganda.

2. Intern Nurse, Habib Medical School, Islamic University in Uganda (HMS- IUIU), Kabale Regional Referral Hospital, Southwestern Uganda.

3. Department of General Surgery, Faculty of Medicine, Istanbul Medeniyet University, Göztepe Training and Research Hospital, Istanbul, Turkey.

4. Africa Health Training and Research Center (MASAM), Istanbul Medeniyet University, Istanbul, Turkey.

Correspondence to: Prof. Dr. Orhan Alimoglu, Department of General Surgery, Faculty of Medicine, Istanbul Medeniyet University, Goztepe Training \& Research Hospital, 34722, Kadikoy, Istanbul, Turkey. E-mail: orhan.alimoglu@medeniyet.edu.tr 
reduce the risk of community transmission. ${ }^{8}$

On March 21 ${ }^{\text {st }}, 2020$, the first case of Covid-19 was confirmed in Uganda, that was a 36-year-old man who had travelled to Dubai on March $17^{\text {th }}$, 2020. ${ }^{9}$ Ever since the index case was identified, there has been a gradual increase in the number of Covid-19 cases in the country most of which are imported cases mainly through travelers and truck drivers. ${ }^{10,11}$ Following the increase in numbers of Covid-19 in the country, the head of the state put forward various strategies in order to curb community transmission of the virus. ${ }^{6}$ These included closure of schools, country lockdown, social distancing rules, hand washing and the use of face masks for the essential workers such as health workers. ${ }^{12}$ However, as the lockdown is being eased amidst raising number of cases within the population, the president of Uganda, with guidance of the ministry of health, made it mandatory to wear masks while in public and punishable by law if not used. ${ }^{13}$

In many countries, public wearing of masks has been considered as one of the key preventative measures of Covid-19 transmission. ${ }^{14,15}$ Community-wide mask wearing may contribute to the control of Covid-19 by reducing the amount of emission of infected saliva and respiratory droplets from persons with subclinical or mild Covid-19. ${ }^{16,17}$ However, use of masks in public and in health care facilities has been controversial as different organizations and agencies established different guidelines. ${ }^{18}$ The World Health Organization recommends surgical masks for health workers providing routine care to coronavirus disease patients, whereas the US Centers for Disease Control and Prevention recommend N95 respirators. ${ }^{19,20}$

In their review of 172 observational studies, $\mathrm{Chu}$ et al. analyzed 44 comparative studies on evidence obtained from SARS, MERS, Covid-19 and on beta coronaviruses causing these diseases and reported that the use of masks prevented infection. ${ }^{15}$ The respiratory mask has been found to reduce the risk of transmission by $67 \%$, and the N95 mask by $96 \%$ in healthcare professionals. In total, the use of masks reduced the risk of infection by $85 \%$. In addition, eye protection was found to reduce the risk of infection by $78 \%$. Infections in healthcare workers can result in not only deaths, but also the quarantine of many healthcare professionals which can lead to outbreaks in hospitals and to disruption in the health system.

Most authorities recommend that there's no need for the community members to wear a mask, and that masks should only be worn by sick patients. ${ }^{15}$ On the other hand, evidence suggest that, if wearers are compliant to the standard precautions of wearing masks, the use of masks provide protection in high transmission settings such as the public and health care settings, and are more effective if used early when combined with hand hygiene. ${ }^{17,21-24}$ Hence, it is necessary to wear masks in high transmission settings; such as workplaces, busses, trains, planes and other closed settings. ${ }^{18,15}$ In Uganda, not any reports on mask utilization practices have been published yet. Therefore, this report aims at documenting mask use practices, as observed in our interactions with non-Covid-19 patients and their relatives at Kabale regional referral hospital as well as Kabale town residents. It was observed that many non-Covid-19 patients and the relatives of hospitalized patients only wear their masks on reaching the hospital premises and wearing them off as soon as they leave the hospital gates. This behavior has been considered as a result of implementing guidelines of hospital Covid-19 task force which only allows individuals with face masks to enter the hospital gates to access health services.

Furthermore, it was observed that community members of Kabale town wear their masks in the presence of security agencies who may intercept their movements as security officers follow the directives of the president. ${ }^{13}$ Additionally, individuals in the public only wear masks in places where they would be refused from services without masks and remove them as soon as they leave such facilities such as banks, supermarkets, markets and public offices.

In conclusion, wearing of masks in public places and health care facilities together with other preventive measures including hand hygiene, social distancing and wearing of full personal protective equipment for health care providers working on Covid-19 patients are key measures in preventing the spread of infection. ${ }^{17,19,22,25}$ Despite the known benefits of wearing face masks, individuals in Kabale town, Kabale district of Uganda seem to wear masks to please health workers at Kabale regional referral hospital and security officers at different points where they encounter with them. More comprehensives studies are necessary to explore the utilization practices regarding the use of face masks, perceptions and contributory factors in Kabale community. This report also highlights the increased need for the Ugandan ministry of health 
and partner organizations to intensify community educational activities on public awareness of the importance of appropriate use of masks. These include both urban and rural communities who may not have access to radio and televisions since most of the current preventive measures on Covid-19 are aired or televised. This may help communities embrace behavioral changes having arised due to the Covid-19 pandemic.

Conflict of Interest: The corresponding author and other co-authors declare that no conflict of interest exists.

Funds: The authors declare that no funding exists. Ethical Approval issue: Not applicable. Author Contributions:

Mustafa Ssaka: Literature search, data collection, data analysis, manuscript writing, final approval of the version to be published, agreement to be accountable for all aspects of the work in ensuring that questions related to the accuracy or integrity of any part of the work are appropriately investigated and resolved.

Charles Lwanga: Literature search, data collection, data analysis, manuscript writing, final approval of the version to be published, agreement to be accountable for all aspects of the work in ensuring that questions related to the accuracy or integrity of any part of the work are appropriately investigated and resolved.

Tunc Eren: Literature search, data collection, data analysis, manuscript writing, manuscript editing, critical revision, final approval of the version to be published, agreement to be accountable for all aspects of the work in ensuring that questions related to the accuracy or integrity of any part of the work are appropriately investigated and resolved designation of the study and performed the research.

Orhan Alimoglu: Project development, data collection and management, data analysis, manuscript editing, critical revision, final approval of the version to be published, agreement to be accountable for all aspects of the work in ensuring that questions related to the accuracy or integrity of any part of the work are appropriately investigated and resolved.

\section{References:}

1. Zhou F, Yu T, Du R, Fan G, Liu Y, Liu Z, Xiang J, Wang Y, Song B, Gu X, Guan L, Wei Y, Li H, Wu X, Xu J, Tu S, Zhang Y, Chen H, Cao B. Clinical Course and Risk Factors for Mortality of Adult Inpatients With COVID-19 in Wuhan, China: A Retrospective Cohort Study. Lancet 2020;395(10229):1054-62. doi: 10.1016/S0140-6736(20)30566-3

2. Chan JFW, Kok KH, Zhu Z, Chu H, To KKW, Yuan S, Yuen KY. Genomic characterization of the 2019 novel human-pathogenic coronavirus isolated from a patient with atypical pneumonia after visiting Wuhan. Emerg Microbes Infect 2020;9(1):221-36. doi: $10.1080 / 22221751.2020 .1719902$

3. World Health Organization. WHO Director-General's opening remarks at the media briefing on COVID-19 - 11 May 2020. Accessed: 3 June 2020. https://www. who.int/dg/speeches/detail/who-director-general-sopening-remarks-at-the-media-briefing-on-covid-19--11-may-2020
4. Lunn P, Belton C, Lavin C, McGowan F, Timmons $\mathrm{S}$, Robertson D. Using behavioural science to help fight the coronavirus. ESRI Working Paper 2020;656. Accessed: 15 June 2020. http://aei.pitt.edu/102644/

5. World Health Organization. Coronavirus disease (COVID-19) Situation Report - 133. Accessed: 5 June 2020. https://www.who.int/docs/default-source/ coronaviruse/situation-reports/20200601-covid-19sitrep-133.pdf?sfvrsn=9a56f2ac_4

6. Ministry of Health, Republic of Uganda. Update on the Covid-19 outbreak in Uganda. Accessed: 15 June 2020. https://www.health.go.ug/document/updateon-the-Covid-19-outbreak-in-uganda/

7. Cheng VCC, Wong SC, To KKW, Ho PL, Yuen KY. Preparedness and proactive infection control measures against the emerging novel coronavirus in China. J Hosp Infect 2020;104(3):254-5. doi:10.1016/j. jhin.2020.01.010

8. Cheng VCC, Wong SC, Chen JHK, Yip CCY, Chuang VWM, Tsang OTY, Sridhar S, Chan JFW, Ho PL, 
Yuen KY. Escalating infection control response to the rapidly evolving epidemiology of the coronavirus disease 2019 (COVID-19) due to SARS-CoV-2 in Hong Kong. Infect Control Hosp Epidemiol 2020;41(5):493-8. doi:10.1017/ice.2020.58

9. Makerere University. Characteristics and outcomes of initial patients diagnosed and treated with COVID 19 in Uganda. Accessed: 22 May 2020. https:// covid19.munilabs.org/wp-content/uploads/2020/06/ COVIDEPI-Makerere-University-Report.pdf

10. Uganda Virus Research Institute. 8 new COVID-19 cases confirmed on 4th May 2020. Accesssed: 5 May 2020. https://www.uvri.go.ug/news/8-new-covid-19cases-confirmed-4th-may-2020

11. The Independent. UGANDA: 30 new COVID cases. Accessed: 8 June 2020. https://www.independent. co.ug/uganda-30-new-covid-cases/

12. Uganda Media Centre Ministry of ICT and National Guidance, Republic of Uganda. President Museveni address to the nation on matters regarding corona virus. Accessed: 8 May 2020. https://www. mediacentre.go.ug/media/president-museveniaddress-nation-matters-regarding-corona-virus

13. Eastern Africa Consortium for Clinical Research (EACCR2). Covid-19 Updates: 13th Presidential Address. Accessed: 4 May 2020. https://www.eaccr. org/covid-19-updates-13th-presidential-address

14. Ministry of Health, Republic of Uganda. National Guidelines for Management of Covid-19. Accessed: 15 June 2020. https://www.health.go.ug/covid/ document/national-guidelines-for-management-ofcovid-19/

15. Chu DK, Akl EA, Duda S, Solo K, Yaacoub S, Schünemann HJ, COVID-19 Systematic Urgent Review Group Effort (SURGE) study authors. Physical distancing, face masks, and eye protection to prevent person-to-person transmission of SARSCoV-2 and COVID-19: a systematic review and meta-analysis. Lancet 2020;S0140-6736(20)311429. doi:10.1016/S0140-6736(20)31142-9

16. Cheng VC, Wong SC, Chuang VW, So SYC, Chen JHK, Sridhar S, To KKW, Chan JFW, Hung IFN, Ho PL, Yuen KY. The role of community-wide wearing of face mask for control of coronavirus disease 2019 (COVID-19) epidemic due to SARS-CoV-2. J Infect 2020;81(1):107-14. doi:10.1016/j.jinf.2020.04.024

17. World Health Organization. Advice on the use of masks in the context of COVID-19. Accessed: 8 June 2020. https://www.who.int/publications/i/item/ advice-on-the-use-of-masks-in-the-communityduring-home-care-and-in-healthcare-settings-in-thecontext-of-the-novel-coronavirus-(2019-ncov)-outbr- eak

18. Chen N, Zhou M, Dong X, Qu J, Gong F, Han Y, Qiu Y, Wang J, Liu Y, Wei Y, Xia J, Yu T, Zhang X, Zhang L. Epidemiological and clinical characteristics of 99 cases of 2019 novel coronavirus pneumonia in Wuhan, China: a descriptive study. Lancet 2020;395(10223):507-13. doi:10.1016/S01406736(20)30211-7

19. World Health Organization. Infection prevention and control during health care when novel coronavirus $(\mathrm{nCoV})$ infection is suspected. Accessed: 8 June 2020. https://www.who.int/publications/i/item/10665331495

20. Centers for Disease Control and Prevention (CDC). Infection Control Guidance for Healthcare Professionals about Coronavirus (COVID-19). Accessed: 15 June 2020. https://www.cdc.gov/ coronavirus/2019-ncov/hcp/infection-control.html

21. Chughtai AA, Seale H, Islam MS, Owais M, Macintyre CR. Policies on the use of respiratory protection for hospital health workers to protect from coronavirus disease (COVID-19). Int $\mathrm{J}$ Nurs Stud 2020;105:103567. doi:10.1016/j. ijnurstu.2020.103567

22. MacIntyre CR, ChughtaiAA.Arapid systematic review of the efficacy of face masks and respirators against coronaviruses and other respiratory transmissible viruses for the community, healthcare workers and sick patients. Int J Nurs Stud 2020;108:103629. doi:10.1016/j.ijnurstu.2020.103629

23. Cowling BJ, Chan KH, Fang VJ, Cheng CKY, Fung ROP, Wai W, Sin J, Seto WH, Yung R, Chu DWS, Chiu BCF, Lee PWY, Chiu MC, Lee HC, Uyeki TM, Houck PM, Peiris JSM, Leung GM. Facemasks and hand hygiene to prevent influenza transmission in households: a cluster randomized trial. Ann Intern Med 2009;151(7):437-46. doi:10.7326/0003-4819151-7-200910060-00142.

24. MacIntyre CR, Cauchemez S, Dwyer DE, Seale H, Cheung P, Browne G, Fasher M, Wood J, Gao Z, Booy R, Ferguson N. Face mask use and control of respiratory virus transmission in households. Emerg Infect Dis 2009;15(2):233-41. doi:10.3201/ eid1502.081167.

25. Howard J, Huang A, Li Z, Tufekci Z, Zdimal V, van der Westhuizen H, von Delft A, Price A, Fridman L, Tang L, Tang V, Watson GL, Bax CE, Shaikh R, Questier F, Hernandez D, Chu LF, Ramirez CM, Rimoin AW. Face Masks Against COVID-19: An Evidence Review. Preprints 2020;2020040203. doi:10.20944/preprints202004.0203.v2. 